\title{
Pengaruh Penggunaan Repelen Masal Jangka Panjang Pada Suatu Pemukiman terhadap Keberadaan Nyamuk Aedes aegypti (L.) (Diptera: Culicidae)
}

\section{UPIK K. HADI, SINGGIH H. SIGIT, D. J. GUNANDINI, S. SOVIANA, SUGIARTO}

Bagian Parasitologi dan Entomologi Kesehatan, Departemen Ilmu Penyakit Hewan dan Kesehatan Masyarakat Veteriner Fakultas Kedokteran Hewan IPB

(diterima November 2008, disetujui Januari 2008)

\begin{abstract}
A Study of The Effect of Mass Treatment of Repellent on Aedes aegypti (L.) (Diptera: Culicidae). Larval populations was carried out during 14week period at Laladon village Bogor. A total of 3684 respondents were treated and 202 houses were surveyed for house index (HI), container index (CI), and breteau index (BI). The results showed that long-term mass treatments were effective to decrease $64.85 \%$ of the HI, $27.15 \%$ CI and $13.57 \%$ of BI, up to three weeks after the last application of the repellent. Final checks which were done four weeks later resulted HI as low as $13.86 \%$, CI $7.68 \%$, and BI $3.84 \%$, compared to those at the beginning of the survey which were $73.27 \%, 31.87 \%$ and $15.93 \%$, respectively.
\end{abstract}

KEY WORDS: Aedes aegypti, repellent, breteau index, container index, house index

\section{PENDAHULUAN}

Nyamuk Aedes aegypti (L.) Diptera : Culicidae), yang merupakan serangga vektor penyakit demam berdarah dengue (DBD) berkembangbiak pada permukiman manusia. Penyakit DBD sejauh ini menjadi masalah kesehatan masyarakat di kota-kota besar. Penanggulangan dan pencegahannya lebih banyak mengandalkan pada pemutusan rantai penularan melalui pengendalian $A$. aegypti dan $A$. albopictus yang keduanya berperan sebagai vektor penular DBD (WHO 2000).
Upaya pengendalian nyamuk $A$. aegypti saat ini yang terpopuler adalah pengasapan dengan menggunakan insektisida dan gerakan $3 \mathrm{M}$ yaitu menutup, menguras dan menimbun lokasi yang dapat menjadi tempat perkembangbiakan larva nyamuk. Bahkan sekarang, upaya tersebut telah berkembang menjadi $3 \mathrm{M}$ plus yaitu disertai dengan cara perlindungan diri lainnya yang dapat dilakukan oleh masyarakat seperti penggunaan anti nyamuk bakar, aerosol, repelen dan lainnya. Umumnya repelen adalah insektisida yang dapat mencegah gigitan nyamuk. Berbagai ragam formulasi produk repelen yang ada di 
pasaran saat ini termasuk bentuk aerosol, lotion dan krem yang dapat melindungi diri dari gigitan nyamuk secara perorangan atau pribadi dalam kurun waktu tertentu (temporer). Repelen nyamuk umumnya mengandung dietil toluamid, dimetil ftalat dan ikaridin yang dapat bekerja selama beberapa jam (Sigit 2006)

Kemampuan nyamuk menjadi vektor penyakit berkaitan dengan populasi dan aktivitas menghisap darah. Aktivitas menghisap darah diperlukan oleh nyamuk betina untuk proses produksi telur demi kelanjutan keturunannya (Hadi \& Koesharto 2006). Apabila aktivitas menghisap darah tersebut dihalangi oleh penggunaan repelen secara massal pada suatu lokasi, maka dapat diharapkan terjadi hal-hal berikut ini. Pertama, nyamuk berpindah ke tempat lain untuk mencari makan (darah), akibatnya populasi nyamuk di lokasi semula akan menurun karena sebagian besar individu nyamuk berpindah tempat dan tidak kembali lagi. Kedua, meskipun nyamuk hanya sedikit saja yang berpindah, produksi telurnya akan jauh menurun akibat terhambatnya pasokan darah. Kedua keadaan ini mengakibatkan menurunnya populasi nyamuk di lokasi penggunaan repelen massal itu. Dengan menurun, bahkan "menghilangnya" populasi A. aegypti, dapat diharapkan kondisi itu akan mencegah merebaknya kasus demam berdarah pada permukiman tersebut.

Pada penelitian ini pengukuran keberadaan nyamuk $A$. aegypti tidak berdasarkan pada nyamuk dewasanya, tetapi pada keberadaan jentiknya. Ukuran-ukuran standar kepadatan jentik yang digunakan meliputi House Index, Container Index; dan Breteau Index (WHO 1975; Hasyimi \& Soekirno 2004).

Tujuan penelitian ini adalah untuk mengetahui pengaruh penggunaan repelen secara massal dalam periode waktu yang panjang pada suatu permukiman, terhadap keberadaan nyamuk $A$. aegypti.

\section{BAHAN DAN METODE}

\section{Lokasi dan Waktu Penelitian}

Penelitian dilakukan di empat Rukun warga atau RW (RW 2, RW 3, RW 8 dan RW 9) di Desa Laladon Kecamatan Ciomas, Kabupaten Bogor. Selain merupakan desa binaan IPB dalam pembentukan kader jumantik, penentuan lokasi di keempat RW berdasarkan pada letaknya yang cukup terisolasi dari RW lainnya karena dikelilingi oleh persawahan, sehingga mudah untuk dikontrol. Berdasarkan data yang diperoleh dari kader jumantik, keempat RW tersebut memiliki angka jentik yang tinggi. Survei pemeriksaan jentik dilakukan terhadap 604 rumah $(73 \%)$ dari total keseluruhan populasi rumah yaitu 828 rumah. 
Secara garis besar, penelitian terbagi atas lima tahap. Tahap pertama berlangsung selama tiga minggu, merupakan masa pra-oles repelen dan pada tahap ini setiap seminggu sekali dilakukan pengukuran kepadatan jentik nyamuk $A$. aegypti yang bertujuan untuk memperoleh informasi/data awal populasi jentik. Tahap ini disebut sebagai tahap survei atau pra-oles.

Tahap kedua berlangsung selama empat minggu. Selama tahapan ini seluruh penduduk di keempat RW secara massal dan berkala menggunakan repelen dua kali sehari (pagi dan sore hari). Pada periode ini dilakukan pengukuran terhadap jentik nyamuk sebagaimana yang dilakukan pada tahap survei. Tahapan ini disebut tahap evaluasi.

Tahap ketiga adalah tahap pasca oles yang berlangsung selama tiga minggu. Pada tahap ini repelen tidak lagi digunakan atau merupakan masa henti oles repelen, akan tetapi pengukuran terhadap jentik tetap dilakukan untuk mengetahui apakah masih terdapat dampak repelen terhadap populasi jentik nyamuk.

Tahap keempat disebut tahap jeda, yaitu masa selama satu bulan (4 minggu) setelah tahap pasca oles tidak dilakukan pemeriksaan jentik atau kunjungan ke responden.

Tahap kelima atau tahap pengukuran akhir adalah masa kembali dilakukannya pemeriksaan jentik terakhir. Kegiatan ini dilakukan hanya sekali dan bertujuan untuk mengetahui proteksi repelen setelah masa henti oles dan dilakukan setelah tahap jeda untuk menghindari bias keberadaan jentik akibat intervensi manusia.

\section{Bahan yang Diuji}

Repelen yang digunakan dalam penelitian ini adalah repelen komersial yang mengandung bahan aktif diethyltoluamide $13 \%$ yang diproduksi oleh PT Marketama Indah, Jakarta.

\section{Pengambilan Contoh}

Rumus yang umum dipakai untuk menentukan besarnya contoh adalah sebagaimana Depkes (1983):

$$
\mathrm{n}=\frac{\mathrm{t}^{2} \cdot \mathrm{p} \cdot \mathrm{q}}{\mathrm{d}^{2}} \quad \mathrm{q}=(1-\mathrm{p})
$$

$\mathrm{n}=$ Perkiraan awal dari besarnya sampel.

$\mathrm{t}=$ Confidence (untuk 95\% nilainya 1,96).

$\mathrm{d}=$ Precision (besarnya ditentukan $0,05$ atau 0,10$)$.

$\mathrm{p}=$ Proporsi dalam populasi yang memiliki karakteristik tertentu.

$\mathrm{q}=$ Proporsi dalam populasi yang tidak memiliki karakteristik tertentu yang besarnya (1-p).

Setelah ditentukan nilai n, kemudian untuk menentukan besarnya sampel akhir, digunakan rumus:

$$
\mathrm{nf}=\frac{\mathrm{n}}{1+\frac{\mathrm{n}}{\mathrm{N}}}
$$

$\mathrm{nf}=$ Besarnya sampel akhir. 
$\mathrm{N}=$ Besarnya populasi yang akan diselidiki.

\section{Metode Pengolesan}

Pengolesan dilakukan setiap hari pada setiap orang penduduk di empat RW, pada bagian-bagian tubuh yang tidak tertutup oleh busana. Pengolesan dilakukan pukul 06.00 pagi dan 06.00 sore sesudah mandi sebanyak satu sachet untuk setiap orang, selama empat minggu.

\section{Pemeriksaan Jentik}

Pemeriksaan jentik dilakukan sekali seminggu pada $24 \%$ dari jumlah rumah di setiap RW. Umumnya rumah yang dimiliki oleh penduduk mempunyai tipe dan ukuran yang serupa dengan pemilikan satu kamar mandi, dapur, serta lingkungan yang tidak teratur. Kegiatan pemeriksaan jentik ini melibatkan 10 tim, setiap tim terdiri atas 1 kader dan 2 mahasiswa (total 10 kader dan 20 mahasiswa).

\section{Analisis Data}

Penelitian dilakukan dengan dua metode pokok yaitu (1) mengukur keberadaan nyamuk melalui keberadaan jentiknya, dan kedua (2) mengevaluasi/membandingkan kepadatan jentik nyamuk, sebelum, selama dan sesudah penggunaan repelen.

Pengukuran keberadaan jentik tidak berdasarkan jumlah/populasi jentik pada setiap penampungan air (container), tetapi melalui pengamatan ditemukannya jentik atau single larva index.

Keberadaan jentik nyamuk ditentukan dengan menggunakan nilainilai :

a) House index (HI) : persentase rumah yang mengandung jentik di lokasi penelitian.

b) Container index (CI) : persentase wadah yang mengandung jentik Aedes aegypti di lokasi penelitian.

c) Breteau index (BI) : persentase rumah yang mengandung jentik dari 100 buah rumah di lokasi penelitian.

\section{HASIL DAN PEMBAHASAN}

Desa Laladon, Kecamatan Ciomas, Kabupaten Bogor termasuk daerah permukiman di pinggiran kota yang dapat dikategorikan sebagai padat penduduk. Penelitian ini dilakukan di empat RW di Desa Laladon yaitu RW 2, RW 3, RW 8 dan RW 9 yang terdiri atas 15 RT, karena letaknya yang terisolasi serta memiliki angka jentik yang tinggi, maka daerah tersebut merupakan daerah yang ideal untuk penelitian. Selama masa survei, telah dilakukan pemeriksaan jentik terhadap 604 rumah dari total keseluruhan populasi rumah yaitu 828 rumah. Dengan demikian, maka survei telah berhasil mencakup $73 \%$ dari keseluruhan populasi yang ada. Terhadap 604 rumah di atas, kemudian dilakukan penyeleksian lagi untuk menentukan rumah-rumah yang 
dijadikan responden pada tahap evaluasi. Seleksi tersebut didasarkan pada ditemukannya jentik nyamuk (positif jentik), sehingga didapatkan 202 rumah yang dijadikan sebagai responden dan tersebar secara merata di 15 RT dari 4 RW.

Jumlah Kepala Keluarga (KK) yang terdata dari $4 \mathrm{RW}$ adalah $954 \mathrm{KK}$, dengan jumlah penduduk 3.864 jiwa. Selama penelitian berlangsung, seluruh warga tidak disarankan untuk melakukan pengurasan tempat penampungan air (bak mandi, tempayan, bak WC, ember, dll), sehingga diharapkan mengurangi intervensi manusia terhadap keberadaan jentik nyamuk.

\section{Rumah Positif Jentik}

Hasil pengamatan terhadap rumah positif jentik selama masa penelitian disajikan pada Gambar 1. Disini terlihat pada tahap survei atau masa pra oles, jumlah rumah yang positif jentik adalah 148 rumah. Selanjutnya pada tahap evaluasi I atau seminggu setelah seluruh penduduk menggunakan repelen, rumah yang positif jentik turun menjadi 41 rumah. Angka positif jentik mengalami penurunan secara terus menerus, yaitu 30 rumah pada evaluasi II, 27 rumah pada evaluasi III dan 25 rumah pada evaluasi IV. Pada tahap pasca oles atau tiga minggu setelah penghentian pengolesan, angka rumah positif jentik tetap mengalami penurunan, yaitu 19 rumah pada pasca oles I, 18 rumah pada pasca oles II dan 14 rumah pada pasca oles III. Pada tahap pemeriksaan akhir setelah satu bulan pasca oles, rumah positif jentik memperlihatkan peningkatan kembali, yaitu menjadi 28 rumah. Hal ini menunjukkan bahwa proteksi oleh repelen komersial tersebut mulai menurun sekurangnya 3 minggu setelah masa henti oles (tahap pasca oles) berakhir.

\section{Angka Jentik (Larval Index)}

Angka jentik yang ditunjukkan dengan House Index (HI), Container Index (CI) dan Breteau Index (CI) di lokasi penelitian secara lengkap disajikan pada Tabel 1. Dari data terlihat bahwa nilai rata-rata HI pada tahap survei dibandingkan terhadap tahap evaluasi mengalami penurunan yang signifikan yaitu sebesar 58,05\% . Penurunan terus terjadi sampai 3 minggu setelah penghentian pengolesan repelen (tahap pasca oles), hingga mencapai $64,85 \%$ apabila dibandingkan terhadap tahap survei (pra-oles). Setelah 4 minggu tidak dilakukan pengamatan jentik, yang berarti tidak dilakukan kunjungan ke responden, angka HI kembali meningkat pada sekali pengamatan di tahap pasca oles akhir yang mencapai $13,86 \%$.

Adapun nilai rata-rata CI pada tahap evaluasi $(7,80 \%)$ dan tahap pasca 


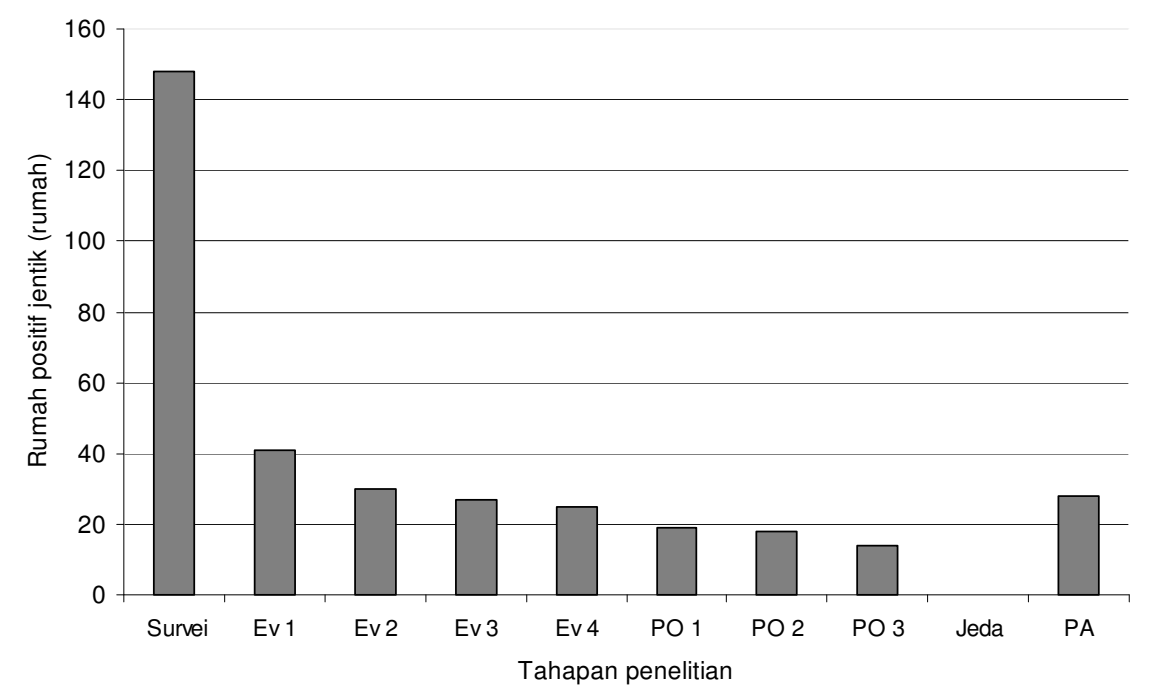

Gambar 1. Rumah positif jentik di empat RW Desa Laladon, Kecamatan Ciomas Bogor selama masa penelitian. Ev: Tahap evaluasi; PO: Tahap pasca oles; Jeda: Tahap jeda (4 minggu tidak dilakukan pengamatan/kunjungan ke responden); PA: Tahap pemeriksaan akhir.

Tabel 1. Rata-rata angka jentik (larval index) di empat RW, Desa Laladon, Kecamatan Ciomas, Bogor

\begin{tabular}{lcccc}
\hline \hline & $\begin{array}{c}\text { Survei } \\
(\%)\end{array}$ & $\begin{array}{c}\text { Evaluasi } \\
(\%)\end{array}$ & $\begin{array}{c}\text { Pasca Oles } \\
(\%)\end{array}$ & $\begin{array}{c}\text { PO akhir } \\
(\%)\end{array}$ \\
\hline House Index $(\mathrm{HI})$ & 73,27 & 15,22 & 8,42 & 13,86 \\
Container Index $(\mathrm{CI})$ & 31,87 & 7,80 & 4,72 & 7,68 \\
Breteau Index $(\mathrm{BI})$ & 15,93 & 3,90 & 2,36 & 3,84 \\
\hline
\end{tabular}

oles $(4,72 \%)$ menurun dibandingkan dengan nilai rata-rata pada tahap survei $(31,87 \%)$ dan pada tahap pemeriksaan terakhir meningkat lagi menjadi $7,68 \%$. Demikian pula nilai rata-rata BI pada tahap evaluasi $(3,9 \%)$, pasca oles $(2,36 \%)$, dan pada pemeriksaan terakhir $(3,84 \%)$, juga cenderung menyerupai gambaran seperti pada nilai CI. Penurunan angka jentik yang terjadi selama penelitian secara lengkap disajikan pada Gambar 2.

Berdasarkan hasil penelitian secara umum terlihat adanya gambaran bahwa penggunaan repelen masal jangka panjang pada suatu permukiman dapat menurunkan keberadaan jentik $A$. aegypti. Hal ini tercermin dari angka- 


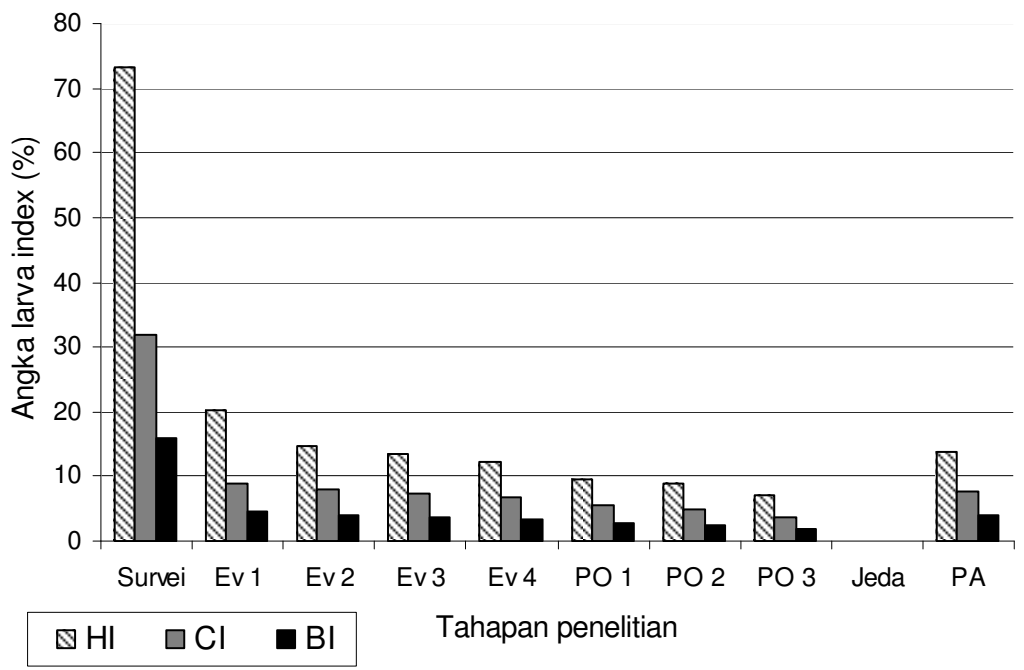

Gambar 2. Angka Jentik (HI, CI, dan BI) di empat RW Desa Laladon, Kecamatan Ciomas, Bogor selama penelitian Ev: Tahap evaluasi; PO: Tahap pasca oles; Jeda: Tahap jeda (4 minggu tidak dilakukan pengamatan/kunjungan ke responden); PA: Tahap pemeriksaan akhir.

angka keberadaan jentik (HI, CI dan BI). Walaupun angka HI pada tahap pengukuran akhir atau setelah masa henti oles, kembali meningkat tetapi peningkatan ini masih dalam kisaran angka HI di tahap evaluasi (masa oles). Dengan demikian dapat dinyatakan bahwa daya proteksi repelen komersial ini masih terlihat hingga akhir penelitian atau sekitar 8 minggu setelah repelen tidak lagi gunakan. Angka CI yang merupakan angka keberadaan jentik nyamuk dibandingkan terhadap jumlah seluruh wadah yang diperiksa yang ada dalam rumah responden, pada tahap evaluasi juga menunjukkan penurunan yang berarti yaitu sebesar 24,07\% jika dibandingkan terhadap angka CI pada tahap survei (pra-oles). Seperti halnya dengan HI, angka CI terus menurun hingga akhir tahap pasca oles yang mencapai penurunan sebesar $27,15 \%$ jika dibandingkan terhadap tahap survei (pra-oles). Peningkatan angka CI pada tahap pemeriksaan akhir atau setelah 4 minggu tidak dilakukan pengamatan jentik juga masih dalam kisaran angka CI pada tahap evaluasi.

Angka BI merupakan pengukuran terbaik yang digunakan untuk memperkirakan densitas jentik, karena sudah mengkombinasikan keduanya baik rumah maupun wadah. Berdasarkan penghitungan angka BI terlihat bahwa dengan pengolesan repelen komersial secara masal dalam jangka waktu 4 (empat) minggu 
ternyata mampu menurunkan tingkat risiko kejadian penyakit demam berdarah di lokasi penelitian.

Menurut WHO (1975) angka BI pada tahap survei (pra-oles) yaitu sebesar $15,93 \%$, termasuk ke dalam skala 3, sedangkan pada tahap evaluasi rata-rata angka BI sebesar 3,90 tergolong ke dalam skala 1. Apabila dikaitkan dengan tingkat risiko kejadian penyakit berdasarkan WHO (1994), maka pada tahap survei (pra oles), keempat RW tergolong ke dalam risiko rendah $(\mathrm{BI}=5-20)$, sedangkan pada tahap evaluasi dan tahap pasca oles tergolong ke dalam risiko aman (BI = 5 atau kurang).

\section{KESIMPULAN}

Dari hasil penelitian ini, dapat disimpulkan bahwa (1) penggunaan repelen masal jangka panjang mampu menurunkan populasi nyamuk di suatu daerah, (2) penggunaan repelen masal jangka panjang mampu menurunkan angka House Index (HI) sebesar 58\%, angka Container Index (CI) sebesar 24\% dan angka Breteau Index sebesar $12 \%$, (3) penurunan angka-angka di atas berlangsung sampai minimal 3 minggu setelah penghentian pengolesan massal.

\section{SARAN}

Berdasarkan hasil penelitian ini, maka disarankan bahwa (1) penggunaan repelen dapat ditambahkan pada program pemerintah dalam menghadapi penyakit DBD yaitu $3 \mathrm{M}$ (Menutup, Menguras dan Mengubur) menjadi $\mathbf{3}$ M plus $\mathbf{1}$ M yaitu mengoleskan repelen, (2) perlu dilakukan penelitian lanjutan mengenai berapa lama masa penurunan angka jentik sampai menunjukkan peningkatan kembali. Informasi ini sangat dibutuhkan karena sebagai informasi pendukung mengenai kemampuan dari repelen dapat menurunkan populasi nyamuk di suatu daerah, dan (3) perlu dilakukan pengamatan dampak penggunaan repelen terhadap pengolesan jangka panjang, mengingat kemungkinan adanya reaksi negatif di antara individu pengguna.

\section{DAFTAR PUSTAKA}

DEPKES. 1983. Petunjuk Penilaian Operasional dalam Rangka Abatisasi Massal. Subdirektorat P 2 Arbovirosis Direktorat P2B2, Depkes RI-Jakarta.

Hadi UK, Koesharto FX. 2006. Nyamuk. Dalam : Sigit, S.H. dan Upik K. Hadi, 2006. Hama Permukiman Indonesia; Pengenalan, Biologi dan Pengendalian. Unit Kajian Pengendalian Hama Permukiman - Bogor. Hal. 23-51.

Hasyimi H, Soekirno M. 2004. Pengamatan Tempat Perindukan Aedes aegypti Pada Tempat Penampungan Air Rumah Tangga Pada Masyarakat Pengguna Air Olahan. Jurnal Ekologi Kesehatan 3 (1) : 37-42.

Sigit SH. 2006. Masalah Hama Permukiman dan Falsafah Dasar 
Pengendaliannya. Dalam : Sigit, S.H. dan Upik K. Hadi, 2006. Hama Permukiman Indonesia; Pengenalan, Biologi dan Pengendalian. Unit Kajian Pengendalian Hama PermukimanBogor. Hal 1-13.

WHO. 1975. Technical Guides for Diagnosis, Treatment, Surveillance Prevention and Control of Dengue Haemorrhagic Fever for South
East Asia and Western Pasific Region.

WHO. 1994. Guidelines for Dengue Surveillance and Mosquito Control. WHO Regional Office for The Western Pasific, Manila.

WHO. 2000. Pencegahan dan Penanggulangan Penyakit Demam Berdarah dan Demam Berdarah Dengue. Terjem. WHO Regional Publication SEARO No. 29. WHO dan Dep.Kes.RI. Hal 53. 